\title{
The recent shift in early summer Arctic atmospheric circulation
}

\author{
James E. Overland, ${ }^{1}$ Jennifer A. Francis, ${ }^{2}$ Edward Hanna, ${ }^{3}$ and Muyin Wang ${ }^{4}$ \\ Received 24 July 2012; revised 30 August 2012; accepted 31 August 2012; published 10 October 2012.
}

[1] The last six years (2007-2012) show a persistent change in early summer Arctic wind patterns relative to previous decades. The persistent pattern, which has been previously recognized as the Arctic Dipole (AD), is characterized by relatively low sea-level pressure over the Siberian Arctic with high pressure over the Beaufort Sea, extending across northern North America and over Greenland. Pressure differences peak in June. In a search for a proximate cause for the newly persistent $\mathrm{AD}$ pattern, we note that the composite $700 \mathrm{hPa}$ geopotential height field during June 2007-2012 exhibits a positive anomaly only on the North American side of the Arctic, thus creating the enhanced mean meridional flow across the Arctic. Coupled impacts of the new persistent pattern are increased sea ice loss in summer, long-lived positive temperature anomalies and ice sheet loss in west Greenland, and a possible increase in Arctic-subarctic weather linkages through higheramplitude upper-level flow. The North American location of increased $700 \mathrm{hPa}$ positive anomalies suggests that a regional atmospheric blocking mechanism is responsible for the presence of the $\mathrm{AD}$ pattern, consistent with observations of unprecedented high pressure anomalies over Greenland since 2007. Citation: Overland, J. E., J. A. Francis, E. Hanna, and M. Wang (2012), The recent shift in early summer Arctic atmospheric circulation, Geophys. Res. Lett., 39, L19804, doi:10.1029/2012GL053268.

\section{Introduction}

[2] Over at least the last six years (2007-2012) there have been shifts in various aspects of northern climate, sometimes referred to as the new normal, new Arctic, or abrupt change [Duarte et al., 2012]. Major features are the loss of old thick sea ice and late summer sea ice extent [e.g., Kwok and Untersteiner, 2011] and reductions in the Greenland ice sheet [e.g., Rignot et al., 2011]. Observations suggest that atmospheric circulation has also changed, although spatial and temporal natural variability is large [e.g., Jaiser et al., 2012; Francis et al., 2009]. While changes in atmospheric circulation are large in autumn and early winter, Overland and Wang [2010] noted a new persistence of an anomalous meridional wind pattern in summer beginning in 2005

\footnotetext{
${ }^{1}$ Pacific Marine Environmental Laboratory, NOAA, Seattle, Washington, USA

${ }^{2}$ Institute of Marine and Coastal Sciences, Rutgers, State University of New Jersey, New Brunswick, New Jersey, USA.

${ }^{3}$ Department of Geography, University of Sheffield, Sheffield, UK.

${ }^{4}$ Joint Institute for the Study of the Atmosphere and Oceans, University of Washington, Seattle, Washington, USA.

Corresponding author: J. E. Overland, Pacific Marine Environmental Laboratory, NOAA, 7600 Sand Point Way NE, Seattle, WA 98115-6349, USA. (james.e.overland@noaa.gov)

(C)2012. American Geophysical Union. All Rights Reserved. 0094-8276/12/2012GL053268
}

associated with higher sea-level pressure (SLP) on the North American side of the Arctic and lower SLP on the Siberian side (Figure 1), which contrasts with the more zonal wind pattern of the Arctic Oscillation (AO) [also see Stroeve et al., 2012, section 5; Ogi and Wallace, 2012, and references therein]. This meridional pattern has been termed the Arctic Dipole (AD), and it contributed substantially to the record summer sea ice loss in 2007 [Wang et al., 2009; Lindsay et al., 2009]. Now with six years of data available since 2007 , it is feasible to investigate more thoroughly early summer atmospheric circulation changes. We note that although intra- and inter-annual variability in intensity and spatial location of meteorological features are still important aspects of the Arctic atmosphere, a recent shift in hemispheric-scale summer patterns is evident. The question of causality in the face of natural variability, especially relating to the location of subarctic blocking high pressure situations, remains challenging.

\section{A Shift in the Early Summer Circulation Pattern During 2007-2012}

[3] An assessment of monthly SLP fields from the NCEP/ NCAR Reanalysis [Kalnay et al., 1996] reveals that the AD pattern as defined below is persistent in 2007-2012 during the month of June, although it is seen in other summer months especially in 2007 (Table 1); this early-summer presence of anomalous Beaufort high SLP was also found by Ogi and Wallace [2012] and Stroeve et al. [2012]. Except for 2012, the AD index beginning in 2007 for the month of June has a stark contrast to values for May. We will focus on June as we are interested in case studies of what larger scale meteorological conditions might help initiate the AD pattern. The formal AD pattern has been defined as the second Empirical Orthogonal Function (EOF) of the extended winter (NDJFM) mean sea-level pressure (MSLP) anomaly north of $70^{\circ} \mathrm{N}$ [Wang et al., 2009; Overland and Wang, 2010]. The first EOF has a local resemblance to the original AO pattern [Thompson and Wallace, 1998]. Figure 2 shows the time series of the regression coefficients of June MSLP anomaly fields projected onto the first two formal limited-area EOFs from Overland and Wang [2010]. Bars show the values of the June-mean AO, and the continuous line is the June AD magnitude. Both time series are normalized by their monthly standard deviation for 1948-2012. A negative AD corresponds to a positive MSLP anomaly in the Beaufort Sea region and a negative MSLP anomaly on the Siberian side of the Arctic Basin, creating anomalous geostrophic winds flowing from the Bering Strait region toward the North Pole and across to the Fram Strait. The recent June AO is also negative, but with large interannual variability.

[4] The only similar AD occurrence during the 63-year time series to recent years is a run of weak negative values 


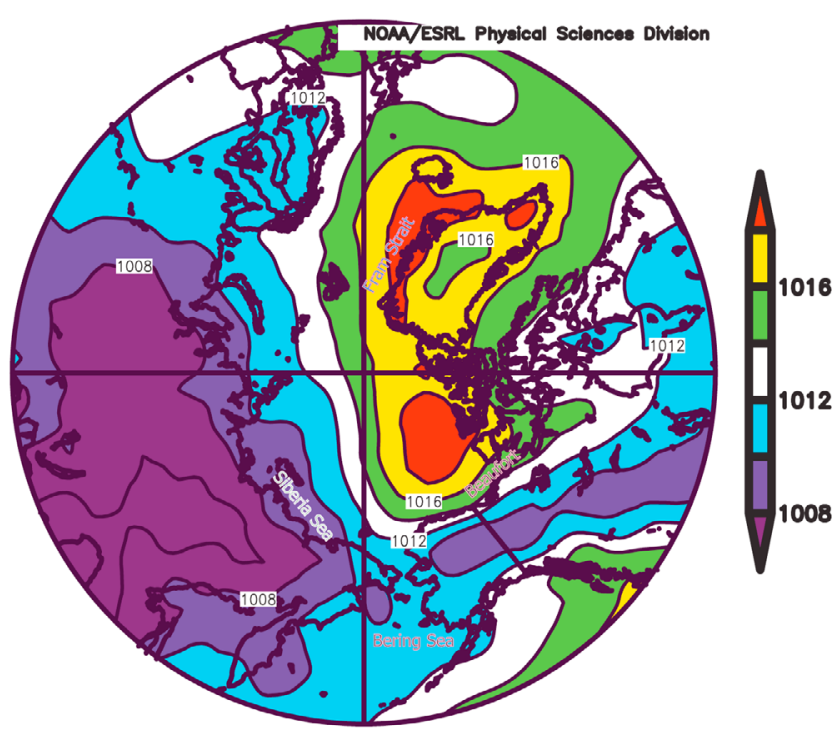

Figure 1. Composite of June sea level pressure (hPa) for 2007-2012. Data are from the NCEP-NCAR Reanalysis through the NOAA/Earth Systems Research Laboratory.

from 1954-1960, when the NCEP/NCAR reanalysis fields had less supporting Arctic data. Thus we can say that a six year run of near one standard deviation negative excursions (2007-2012) is unique in the 63 year record. To further test the significance of the 2007-2012 AD patterns we randomly generated 10,000 time series, each with 63 points to match the observed time series and with a normal distribution without autocorrelation. For this simple calculation, the chance for having five consecutive values with a negative $\mathrm{AD}$ of magnitude greater than 1.0 standard deviation units in a sample size of 63 is rare, less than 1 in a 1000 .

[5] For a mechanistic understanding of the AD pattern, we focus on the $700 \mathrm{hPa}$ geopotential height anomaly for June 2007-2012 (Figure 3a). Patterns are similar for the $925 \mathrm{hPa}$ through $500 \mathrm{hPa}$ geopotential height fields for this month, with additional small scale variability below the $700 \mathrm{hPa}$ level (not shown). Conspicuous positive geopotential height anomalies extend from Greenland northwestward across the Beaufort Sea, with little or no features on the Siberian side or elsewhere north of $50^{\circ} \mathrm{N}$. This anomaly pattern existed in every June from 2007 through 2012, with minor geographic shifts in details.

[6] For comparison, Figure 3b presents the climatological $700 \mathrm{hPa}$ geopotential height field for June, and Figure $3 \mathrm{c}$ is the composite $700 \mathrm{hPa}$ geopotential height field for June 2007-2012. The climatological field exhibits a broad region of low heights that depict a relatively symmetric polar vortex across the central Arctic basin, with one lobe in the Bering Sea associated with the North Pacific Aleutian low center and another over northern Baffin Bay extending into far northeastern Canada. Climatological June winds north of Alaska and along the northern Eurasian continent are characterized by a zonal westerly flow. In the 2007-2012 composite height field (Figure 3c) there is little difference from climatology (Figure $3 \mathrm{~b}$ ) in the low height regions over Eurasia and the Bering Sea. A large change is evident in the cross-Arctic gradient, and thus the geostrophic wind, along the Pacific dateline and extending to Svalbard: the signature of the AD pattern. On the North American side, the high geopotential height ridging structures are enhanced: one extending northward from Alaska and another with a closed height maximum over Greenland. It is clear from Figure 3a that the June $700 \mathrm{hPa}$ geopotential height anomaly field for 2007-2012 has an amplified configuration that persisted only on the North American side of the Arctic during the last six years, corresponding to the amplified ridge over Greenland (Figure 3c). A question of interest is why has this highamplitude pattern remained persistent beginning in 2007 in the North American subarctic?

\section{Impacts}

[7] The June 2007-2012 MSLP field presented in Figure 1 reveals several surface impacts of the recent circulation change. The MSLP field is broadly similar to the recent $700 \mathrm{hPa}$ geopotential height field, but the Beaufort high MSLP center is more pronounced, and the broad low center is shifted over the Asian continent relative to upper level features.

[8] It is well known that the major loss of sea ice cover in the Pacific Arctic in summer 2007 was in part due to the presence of the $\mathrm{AD}$ pattern throughout the summer [e.g., Wang et al., 2009; Stroeve et al., 2012]. Southerly winds along the dateline not only forced ice motion mechanically northward, but they also advected heat and moisture toward the North Pole, which then helped to melt the summer sea ice at higher latitudes [Zhang et al., 2008]. Reduced cloudiness and enhanced insolation [Kay et al., 2008], as well as enhanced ocean heat transport [Woodgate et al., 2010], also contributed to the unprecedented 2007 Arctic sea ice loss. In all summers since 2007, with the possible exception of 2012, the low-level circulation over the Arctic has been more anticyclonic than in prior years, which has contributed to continued near-record lows in September sea ice extent [Ogi and Wallace, 2012]. While the AD pattern persisted during most of the 2007 summer, it occurred consistently in years after 2007 only during June (Table 1), resulting in a 1-to$2 \mathrm{~ms}^{-1}$ stronger wind flow from the Chukchi Sea across the pole and promoting continued sea ice loss through Fram Strait [Wang et al., 2009]. Further, anomalous easterly coastal winds north of eastern Alaska promote offshore transport of warm Mackenzie River water, also contributing to sea ice melt [Dean et al., 1994].

[9] Over west Greenland, the recent summers of 2007 2011 were characterized by unprecedented high pressure relative to a 1948-present baseline. Hanna et al. [2012] relate these pressures to an increased Greenland Blocking

Table 1. Monthly AD Index for 2005-2012

\begin{tabular}{cccccc}
\hline & May & June & July & Aug. & Sept. \\
\hline 2005 & -0.42 & -0.40 & 0.05 & -0.23 & -1.96 \\
2006 & -1.20 & 0.94 & 0.06 & 0.00 & -1.89 \\
2007 & -0.52 & -1.08 & -1.65 & -1.77 & -1.23 \\
2008 & -1.06 & -1.16 & -0.58 & -0.63 & 0.44 \\
2009 & 2.40 & -1.46 & -1.95 & -0.57 & 0.04 \\
2010 & -0.03 & -1.86 & 0.36 & -1.88 & -0.72 \\
2011 & -0.36 & -1.56 & -1.20 & -1.29 & 2.41 \\
2012 & -1.61 & -0.84 & & & \\
\hline
\end{tabular}




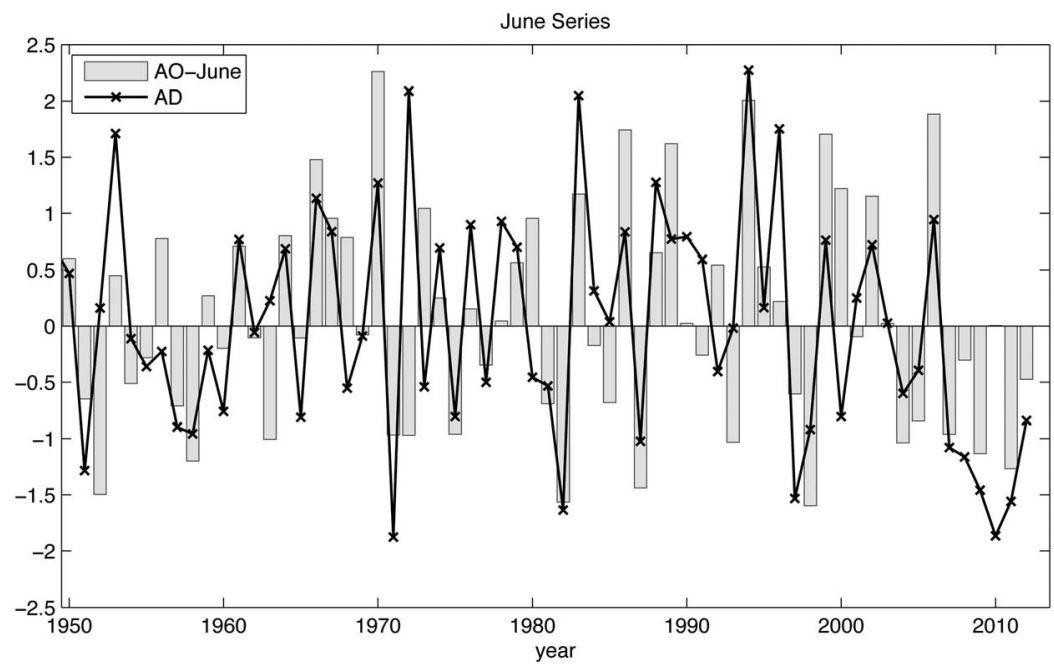

Figure 2. Regression coefficients of the June-mean sea-level pressure anomalies from the NCEP/NCAR Reanalysis projected onto the first two EOF spatial patterns of the extended winter mean sea-level pressure north of $70-90^{\circ} \mathrm{N}$ [from Overland and Wang, 2010]. The June AO is shown by gray bars, and the June AD is shown by blue solid lines. Both time series are normalized by their standard deviation for 1948-2012.

Index (GBI) that promoted anomalously warm summers at coastal stations and an increase in ice-sheet runoff. The same conditions were true in June 2012, which had the highest GBI June value since the start of the NCEP/NCAR Reanalysis data record in 1948. The detrended June GBI for 19482012 is strongly correlated with the $\mathrm{AD}(\mathrm{r}=-0.78)$. Because of the importance of Greenland melt on sea-level rise, the potential impacts of a continued high GBI causing persistent enhanced summer melt in Greenland are significant [Hanna et al., 2008a, 2012; Rignot et al., 2011; van den Broeke et al., 2009].

[10] The suggestion that recent (2007-2012) magnitudes of the early summer $\mathrm{AD}$ pattern are associated with enhanced North America and Greenland blocking events in the $700 \mathrm{hPa}$ composite height field (Figure 3c) may imply a mechanism linking high-latitude change with mid-latitude weather in early summer. Figure 4a shows the June 2012 $700 \mathrm{hPa}$ meridional component of the wind field associated with a strong AD pattern. Alternating regions of northward and southward flow are evident across the subarctic. The corresponding meridional wind anomaly field (not shown) is similar to that in the mean June 2012 wind plot suggesting how unusual June 2012 was compared to climatology. Figure $4 \mathrm{~b}$ presents the corresponding near-surface temperature anomaly field for June 2012, highlighting the heatwave in western Russia and high temperature anomalies from far northeastern Canada extending southwest through the eastern Rocky Mountains in the US. These warm anomalies correspond to areas of southerly wind anomalies. The June $2012700 \mathrm{hPa}$ geopotential height and temperature patterns (not shown) are similar to the Russian heatwave of 2010 [Dole et al., 2011], and the anomalous circulation may also have contributed to dryness and forest fires plaguing central and western US during the 2012 summer. Meanwhile, an enhanced southward dip in the jet stream leeward of the increased ridging over Greenland has caused generally cool
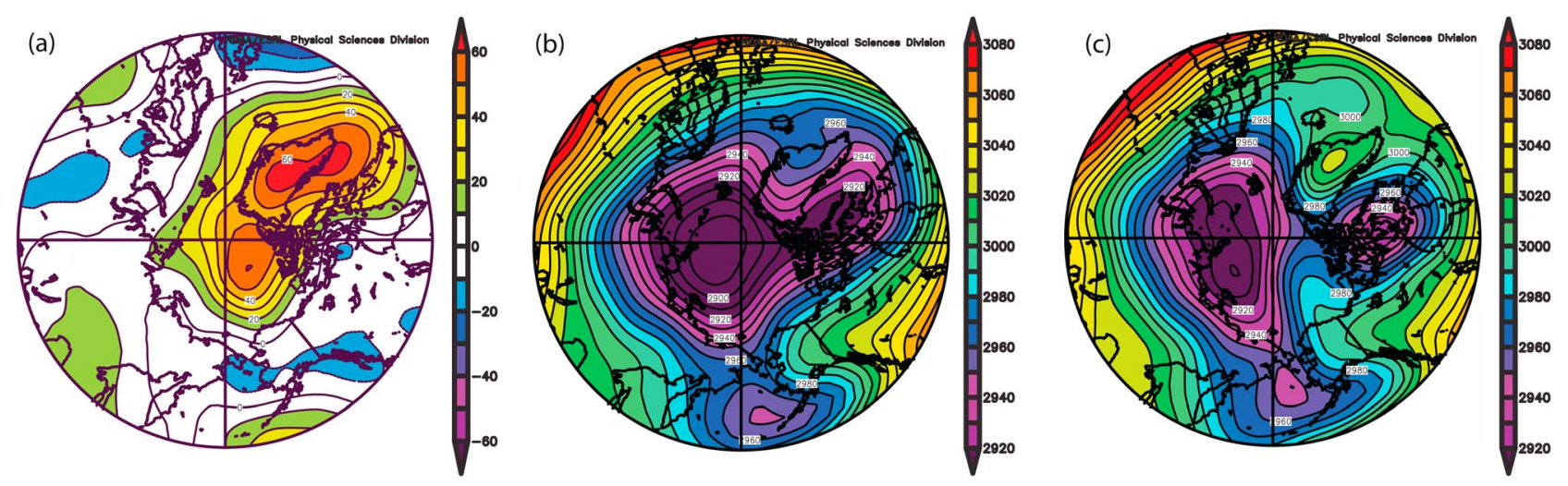

Figure 3. Multi-year composite $700 \mathrm{hPa}$ geopotential height (a) anomaly for June from 2007 through 2012. (b) Climatology for June (1981-2010), and (c) composite of June 2007-2012. Anomalies are relative to 1981-2010 mean. Units are in $\mathrm{m}$. Data are from the NCEP-NCAR Reanalysis through the NOAA/Earth Systems Research Laboratory. 

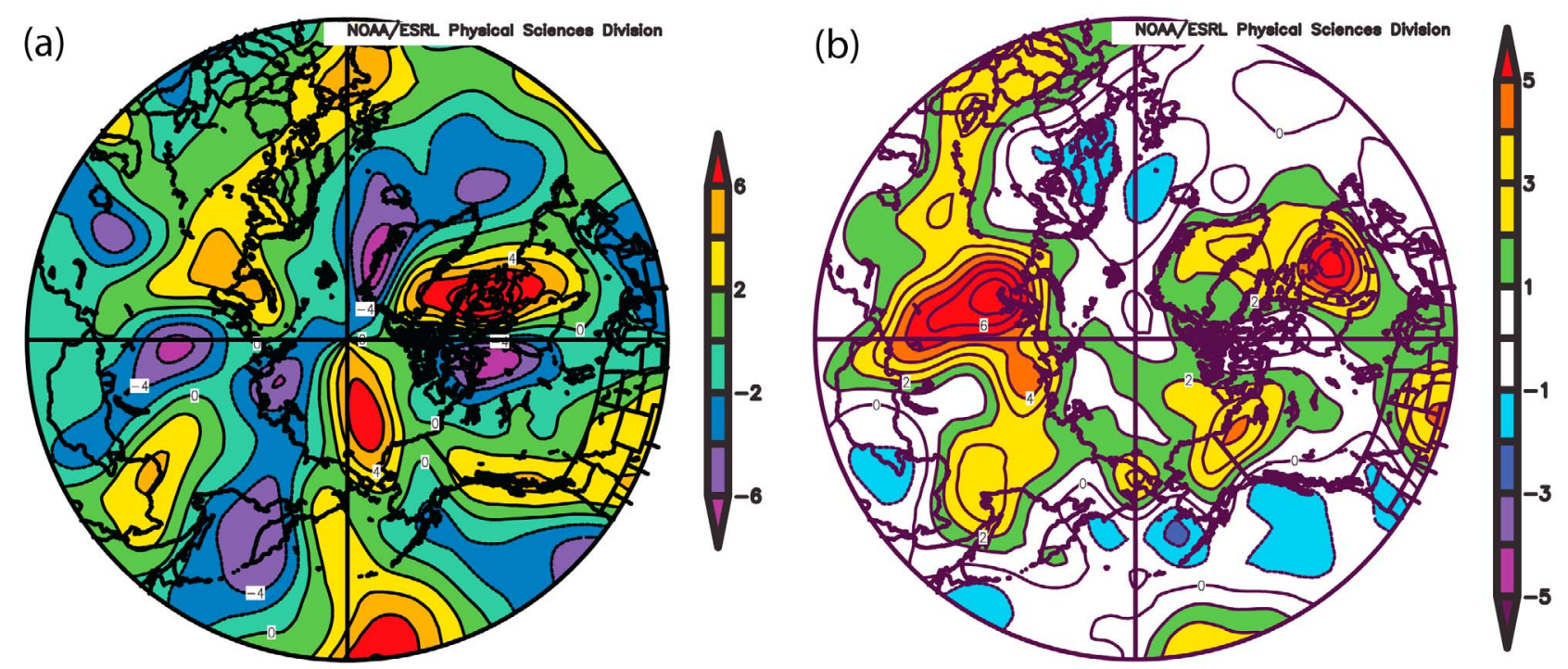

Figure 4. (a) $700 \mathrm{hPa}$ meridional wind component $\left(\mathrm{ms}^{-1}\right)$ and (b) Near-surface air temperature anomaly $\left({ }^{\circ} \mathrm{C}\right)$ for June 2012. Data are from the NCEP-NCAR Reanalysis through the NOAA/Earth Systems Research Laboratory. Note these plots extend further south than Figures 1 and 3.

wet summers in the U.K. since 2007, with record rains and floods in 2007 and 2012 [e.g., Hanna et al., 2008b; Met Office, 2012].

\section{Discussion}

[11] A persistent blocking pattern on the North American side of the Arctic has existed during early summer from 2007 through 2012 (Figures 3a and 3c). The persistence of this pattern for six years suggests a systematic shift in atmospheric circulation relative to the previous time series record. Francis and Vavrus [2012] show a summer increase in $500 \mathrm{hPa}$ ridging and meridional flow in the sub-Arctic from $20-80^{\circ} \mathrm{W}$ longitude beginning in 2007 in response to Arctic amplification. Francis and Vavrus [2012] and Hanna et al. [2012] both discuss a possible mechanism for this shift, where a high wave number hemispheric pattern in geopotential heights, with a wavelength of about $5000 \mathrm{~km}$, is associated with a nearly stationary flow that affects both high- and mid-latitudes. Tachibana et al. [2010] note a connection of summer mid-latitude blocking events with lower geopotential heights over the central Arctic Ocean. Schubert et al. [2011] note the presence of near stationary Rossby waves during summer with extensive latitudinal extent and a preference for extreme events in June. Further, they comment that current GCMs appear deficient in simulating the development of such regional circulation features.

[12] A blocking regime paradigm introduces two opposing ideas. On one hand, blocks tend to be slow-moving but transient phenomena on sub-monthly time scales. They illustrate the chaotic nature of Northern Hemispheric atmospheric circulation with large natural variability [Dole et al., 2011]. Year-to-year and intra-seasonal differences are to be expected. On the other hand, the exceptional heat waves of 2003, 2010 and 2012, result in a recent clustering of outliers [Barriopedro et al., 2011; Otto et al., 2012]. Some year-toyear congruence in recent anomalous large-scale Arctic and subarctic weather patterns is noted by Ogi and Wallace
[2012], Hanna et al. [2012], and Francis and Vavrus [2012], suggesting preferred regions for persistent changes in pressure patterns.

[13] External forcings tied to geographical features, such as changes in snow amount and subsequent effects on soil moisture and surface temperature and albedo, can reinforce blocking patterns and temperature extremes [Namias, 1964; Cohen, 1994; Ge and Gong, 2009; Allen and Zender, 2011; Jaeger and Seneviratne, 2011]. One hypothesis to explain shifts in recent June geopotential height patterns may relate to the dramatically earlier loss of snow cover over large regions of high-latitude northern hemisphere land areas during May and June since the mid-1990s and especially in the previous three years in North America (http://climate. rutgers.edu/snowcover). Snow cover exhibits large interannual spatial variability, thus it is difficult to attribute direct causality with observed changes in blocking over the North American side of the Arctic. The reduced ice cover during spring and early summer in the Hudson Bay region should also play a role by allowing surface waters to warm earlier and contribute to observed SLP anomalies [Joly et al., 2011].

[14] Enhanced Arctic warming may be a key to Arctic/ mid-latitude linkages - in autumn owing to sea ice loss [Liu et al., 2012; Francis and Vavrus, 2012] and in early summer owing to extensive earlier snow melt. The two factors operate through the mechanism of weakening the poleward temperature gradient and affecting meridional atmospheric circulation, as suggested more than a decade ago by Slonosky et al. [1997]. Coarse scale climate models may not be up to the task of resolving such connections [Vial and Osborn, 2012; Orsolini et al., 2012].

\section{Conclusion}

[15] The last six years (2007-2012) show a persistent change in early summer Arctic wind patterns relative to previous decades that suggests an enhancement of the 
so-called Arctic Dipole (AD). The composite $700 \mathrm{hPa}$ geopotential height field during June of 2007-2012 shows a positive anomaly only over the North American side of the Arctic, thus creating an enhanced meridional flow across the Arctic. This observation, along with the coincidence of maximum $\mathrm{AD}$ strength and increases in the Greenland Blocking Index, suggest that a North American atmospheric blocking mechanism contributes to the increased persistence of the AD pattern. We also note the dramatic loss of snow during spring on high-latitude North American land, and earlier melt of sea ice in Hudson Bay, as speculative but possible contributing drivers.

[16] In the search for causality for loss of summer Arctic sea ice and Greenland ice sheets, stating a change in winds due to the presence of the AD and other local factors does not go far enough. In a crude parallel to Aristotle's hierarchy of causes, we can say that the local winds affecting the ice are an efficient cause due to their direct forcing, atmospheric blocking influencing the presence of the $\mathrm{AD}$ is a formal cause providing a regional dynamic context, while the final cause is still unknown, but should be related to northward heat transfer, global warming, and recent loss of snow cover.

[17] Impacts of recent AD persistence affect not only the Arctic, but may extend to extreme weather events in the subarctic and mid-latitudes [Coumou and Rahmstorf, 2012]. These impacts include a contribution to accelerating sea ice loss in summer, continued warming and ice sheet loss in west Greenland, and a possible increase in persistent weather patterns in mid-latitudes owing to hemispheric-scale adjustments in the long-wave structure of the tropospheric geopotential height field. Recent increases in the initiation, persistence, and severity of weather extremes around the hemisphere may be due, at least in part, to the high-latitude forcing of enhanced blocking, particularly over North America and the North Atlantic sectors of the Arctic. But spatial and intra- and interannual variability is to be expected. Additional research is necessary to further elucidate possible linkages between continuing dramatic Arctic change and intermittent impacts throughout the hemisphere.

[18] Acknowledgments. The work is supported by NOAA Arctic Research Project of the Climate Program Office and the Office of Naval Research Ocean, Atmosphere, and Space Research Division. This publication is partially funded by the Joint Institute for the Study of the Atmosphere and Ocean (JISAO) under NOAA Cooperative Agreement NA10OAR4320148, contribution 2064. PMEL contribution 3890.

[19] The Editor and authors thank the two anonymous reviewers for assisting in the evaluation of this paper.

\section{References}

Allen, R. J., and C. S. Zender (2011), The role of eastern Siberian snow and soil moisture anomalies in quasi-biennial persistence of the Arctic and North Atlantic Oscillations, J. Geophys. Res., 116, D16125, doi:10.1029/2010JD015311.

Barriopedro, D., E. M. Fisher, J. Luterbacher, R. M. Trigo, and R. GarcieHerrera (2011), The hot summer of 2010: Redrawing the temperature record map of Europe, Science, 332, 220-224, doi:10.1126/science.1201224.

Cohen, J. (1994), Snow cover and climate, Weather, 49, 150-156, doi:10.1002/j.1477-8696.1994.tb05997.x.

Coumou, D., and S. Rahmstorf (2012), A decade of weather extremes, Nat. Clim. Change, 2, 491-496.

Dean, K. G., W. J. Stringer, K. Ahlnås, C. Searcy, and T. Weingartner (1994), The influence of river discharge on the thawing of sea ice, Mackenzie River Delta: Albedo and temperature analyses, Polar Res., 13, 83-94, doi:10.1111/j.1751-8369.1994.tb00439.x.

Dole, R., M. Hoerling, J. Perlwitz, J. Eischeid, P. Pegion, T. Zhang, X.-W. Quan, T. Xu, and D. Murray (2011), Was there a basis for anticipating the 2010 Russian heat wave?, Geophys. Res. Lett., 38, L06702, doi:10.1029/2010GL046582.

Duarte, C. M., T. M. Lenton, P. Wadhams, and P. Wassmann (2012), Abrupt climate change in the Arctic, Nature Climate Change, 2, 60-62, doi: $10.1038 /$ nclimate 1386

Francis, J. A., and S. J. Vavrus (2012), Evidence linking Arctic amplification to extreme weather in mid-latitudes, Geophys. Res. Lett., 39, L06801, doi:10.1029/2012GL051000.

Francis, J. A., W. Chan, D. Leathers, J. Miller, and D. Veron (2009), Winter northern hemisphere weather patterns remember summer Arctic sea ice extent, Geophys. Res. Lett., 36, L07503, doi:10.1029/2009GL037274.

Ge, Y., and G. Gong (2009), North American snow depth and climate teleconnections patterns, J. Clim., 22, 217-233, doi:10.1175/2008JCLI2124.1.

Hanna, E., P. Huybrechts, K. Steffen, J. Cappelen, R. Huff, C. Shuman, T. Irvine-Fynn, S. Wise, and M. Griffiths (2008a), Increased runoff from melt from the Greenland Ice Sheet: A response to global warming, J. Clim., 21, 331-341, doi:10.1175/2007JCLI1964.1.

Hanna, E., J. Mayes, M. Beswick, J. Prior, and L. Wood (2008b), An analysis of the extreme rainfall in Yorkshire, June 2007, and its rarity, Weather, 63, 253-260, doi:10.1002/wea.319.

Hanna, E., J. M. Jones, J. Cappelen, S. H. Mernild, L. Wood, K. Steffen, and P. Huybrechts (2012), The influence of North Atlantic atmospheric and oceanic forcing effects on 1900-2010 Greenland summer climate and ice melt/runoff, Int. J. Climatol., doi:10.1002/joc.3475, in press.

Jaeger, E. B., and S. I. Seneviratne (2011), Impact of soil moistureatmosphere coupling on European climate extremes and trends in a regional climate model, Clim. Dyn., 36, 1919-1939, doi:10.1007/ s00382-010-0780-8.

Jaiser, R., K. Dethloff, D. Handorf, A. Rinke, and J. Cohen (2012), Impact of sea ice cover changes on the Northern Hemisphere atmospheric winter circulation, Tellus, Ser. A, 64, 11595, doi:10.3402/tellusa.v64i0.11595.

Joly, S., S. Senneville, D. Caya, and F. J. Saucier (2011), Sensitivity of Hudson Bay sea ice and ocean climate to atmospheric temperature forcing, Clim. Dyn., 36, 1835-1849, doi:10.1007/s00382-009-0731-4.

Kalnay, E., et al. (1996), The NCEP/NCAR 40-year reanalysis project, Bull. Am. Meteorol. Soc., 77, 437-471, doi:10.1175/1520-0477(1996) 077<0437:TNYRP $>2.0 . \mathrm{CO} ; 2$.

Kay, J. E., T. L'Ecuyer, A. Gettelman, G. Stephens, and C. O’Dell (2008), The contribution of cloud and radiation anomalies to the 2007 Arctic sea ice extent minimum, Geophys. Res. Lett., 35, L08503, doi:10.1029/ 2008GL033451.

Kwok, R., and N. Untersteiner (2011), The thinning of Arctic sea ice, Phys. Today, 64, 36-41, doi:10.1063/1.3580491.

Lindsay, R. W., J. Zhang, A. Schweiger, M. Steele, and H. Stern (2009), Arctic sea ice retreat in 2007 follows thinning trend, J. Clim., 22, 165-176, doi:10.1175/2008JCLI2521.1.

Liu, J., J. A. Curry, H. Wang, M. Song, and R. M. Horton (2012), Impact of declining Arctic sea ice on winter snowfall, Proc. Natl. Acad. Sci., 109, 4074-4079, doi:10.1073/pnas.1114910109.

Met Office (2012), Met Office confirms wettest June in over a century, news release, Exeter, U. K. [Available at http://www.metoffice.gov.uk/ news/releases/archive/2012/wettest-June.]

Namias, J. (1964), Seasonal persistence and recurrence of European blocking during 1958-1960, Tellus, 16, 394-407, doi:10.1111/j.21533490.1964.tb00176.x

Ogi, M., and J. M. Wallace (2012), The role of summer surface wind anomalies in the summer Arctic sea ice extent in 2010 and 2011, Geophys. Res. Lett., 39, L09704, doi:10.1029/2012GL051330.

Orsolini, Y. J., R. Senan, R. E. Benestad, and A. Melson (2012), Autumn atmospheric response to the 2007 low Arctic sea ice extent in coupled ocean-atmosphere hindcasts, Clim. Dyn., 38, 2437-2448, doi:10.1007/ s00382-011-1169-z.

Otto, F. E. L., N. Massey, G. J. vanOlenborgh, R. G. Jones, and M. R. Allen (2012), Reconciling two approaches to attribution of the 2010 Russian heat wave, Geophys. Res. Lett., 39, L04702, doi:10.1029/ 2011 GL050422.

Overland, J. E., and M. Wang (2010), Large-scale atmospheric circulation changes are associated with the recent loss of Arctic sea ice, Tellus, Ser. A, 62, 1-9, doi:10.1111/j.1600-0870.2009.00421.x.

Rignot, E., I. Velicogna, M. R. van den Broeke, A. Monaghan, and J. Lenaerts (2011), Acceleration of the contribution of the Greenland and Antarctic ice sheets to sea level rise, Geophys. Res. Lett., 38, L05503, doi:10.1029/2011GL046583.

Schubert, S., H. Wang, and M. Suarez (2011), Warm season subseasonal variability and climate extremes in the Northern Hemisphere: The role of stationary Rossby waves, J. Clim., 24, 4773-4792, doi:10.1175/ JCLI-D-10-05035.1.

Slonosky, V. C., L. A. Mysak, and J. Derome (1997), Linking Arctic sea-ice and atmospheric circulation anomalies on interannual and decadal timescales, Atmos. Ocean, 35, 333-366, doi:10.1080/07055900.1997.9649596. 
Stroeve, J. C., M. C. Serreze, M. M. Holland, J. E. Kay, J. Maslanik, and A. P. Barrett (2012), The Arctic's rapidly shrinking sea ice cover: A research synthesis, Clim. Change, 110, 1005-1027, doi:10.1007/ s10584-011-0101-1.

Tachibana, Y., T. Nakamura, H. Komiya, and M. Takahashi (2010), Abrupt evolution of the summer Northern Hemisphere annular mode and its association with blocking, J. Geophys. Res., 115, D12125, doi:10.1029/ 2009JD012894.

Thompson, D. W. J., and J. M. Wallace (1998), The Arctic oscillation signature in the wintertime geopotential height and temperature fields, Geophys. Res. Lett., 25, 1297-1300, doi:10.1029/98GL00950.

van den Broeke, M., J. Bamber, J. Ettema, E. Rignot, E. Schrama, W. van de Berg, E. van Meijgaard, I. Velicogna, and B. Wouters (2009), Partitioning recent Greenland mass loss, Science, 326, 984-986, doi:10.1126/ science. 1178176
Vial, J., and T. Osborn (2012), Assessment of atmosphere-ocean general circulation model simulations of winter Northern Hemisphere atmospheric blocking, Clim. Dyn., 39, 95-112, doi:10.1007/s00382-011-1177-z.

Wang, J., J. Zhang, E. Watanabe, M. Ikeda, K. Mizobata, J. E. Walsh, X. Bai, and B. Wu (2009), Is the Dipole Anomaly a major driver to record lows in Arctic summer sea ice extent? Geophys. Res. Lett., 36, L05706, doi:10.1029/2008GL036706.

Woodgate, R. A., T. Weingartner, and R. Lindsay (2010), The 2007 Bering Strait oceanic heat flux and anomalous Arctic sea-ice retreat, Geophys. Res. Lett., 37, L01602, doi:10.1029/2009GL041621.

Zhang, J., R. Lindsay, M. Steele, and A. Schweiger (2008), What drove the dramatic retreat of arctic sea ice during summer 2007?, Geophys. Res. Lett., 35, L11505, doi:10.1029/2008GL034005. 